\title{
Italian-Americans in Iowa's Coal Mining Industry
}

\author{
DoRothy SCHWIEDER
}

IN 1914, Paulina Biondi left Fiumalbo, a small village in northern Italy, and traveled to the United States. Her destination was Marquisville, Iowa, a coal camp located near Des Moines. Seventeen years old and recently married, Biondi left her family and friends in Italy, fearing that she might never see them again. For the next forty years, she and her husband John lived in various Iowa coal mining communities where John earned his livelihood as a miner. In a recent interview, Biondi was asked why she had immigrated to the United States. She replied, her voice still rising with excitement after having been away from Italy for almost seventy years, "Well you know, it was a big deal to come to America." Apparently others shared her enthusiasm, for between 1914 and 1917, several of Biondi's relatives followed her, along with scores of others from the same northern Italian village. The immigrants' major destination was the Scandia Coal Camp located near Madrid, Iowa. ${ }^{1}$

The decisions of Biondi and her relatives (plus hundreds of other Italian-Americans) to settle in Iowa attest to the fact that while the fertile soil attracted thousands of people into the state,

1. Interview with Paulina Biondi, Madrid, Iowa, September 1979. All interviews cited in this article were conducted privately by the author from 1975 to 1981. 
a second major resource also had great magnetism for the foreign-born. For some four decades, from 1880 to 1920 , the lowa bituminous coal industry attracted emigrants from all over Europe. The majority of foreign-born came from England, Wales, Scotland, Sweden, Italy, and Croatia. Other nationalities represented, although in far fewer numbers, were German, Irish, French, Austrian, Belgian, Hungarian, Danish, and Russian. After 1900, the Italians constituted the largest foreign-born group involved in the lowa mining industry.

Since the settlement of Italian-Americans in Iowa has been a relatively recent phenomenon, it offers an opportunity to broaden historical investigation of their experience by combining oral histories with more traditional historical sources. The use of oral histories makes possible not only a consideration of the immigrants' work experience in Iowa, but also a study of the cultural and occupational traditions that they brought along from the Old Country. Increasingly, social historians like Herbert Gutman are emphasizing the need to study the immigrants' total cultural experience as opposed to only the "work experience." Moreover, as Gutman has pointed out in his book, Work, Culture and Society in Industrializing America, the new workers were not just affected by the specific jobs undertaken; rather they were affected by the total new environment. In Iowa, the recent experience of the Italian-Americans allows for the application of this broader cultural approach.

The Iowa coal mining industry in which Italian-Americans were employed did not develop until the late nineteenth century. Although the earliest settlers extracted coal along rivers and streams, coal operators did not establish systematic prospecting and development until the $1870 \mathrm{~s}$. At that time all main Iowa railroads had reached the Missouri River, thus providing the major impetus for increased coal production. The railroads followed the practice of leasing coal lands and operating the mines as railroad subsidiaries. Known as "captive mines," these workings constituted the largest coal operations in the state. At the same time, smaller operators provided coal for local consumption. By 1895, 342 coal mines were operating in the state with a total of 6,363 miners. While the number of mines remained fairly constant over the next thirty years, the number of 
miners more than doubled. By 1925, Iowa coal mines totaled 354 with approximately 12,000 miners employed. Following 1925 production gradually declined, until by the mid-1950s only a handful of coal mines remained in operation. ${ }^{2}$

Perhaps the most distinctive features of the industry were the dozens of coal camps dotting the landscape of central and southern Iowa. Bleak and dismal in their outward appearance, these short-lived communities stretched from Wapello County in southeastern Iowa upward to Boone County in the central region of the state. The typical camp consisted of several hundred small houses, arranged in straight rows along either side of a main thoroughfare. Owned and operated by the coal company, the camps usually included a company store, a union hall, a tavern or pool hall, and an elementary school. Because the average life span of an Iowa coal mine was ten years, little attention was given to the maintenance of the camps once they were constructed. Within the community, the company store served as the center of activity and provided residents with everything from "cradles to coffins." Most companies required that employees trade only at the company store and few mining families harbored anything but negative feelings toward that operation. ${ }^{3}$

Although the Iowa mining industry had a major impact on the state's economy during the late 1800 s and early 1900 s, its impact on the national economy was slight. Twenty-eight states mined bituminous coal in 1895 with five states-Pennsylvania, Illinois, Ohio, West Virginia, and Alabamá-producing roughly 72 percent of the total tonnage. By comparison Iowa ranked fifteenth, producing around 1 percent of the nation's total. Even if Iowa's coal production was limited, the state's mining operations were still fully integrated with the national industry. As a result, Iowa operators were plagued with the

2. Report of the State Mine Inspectors. 1880-1925. (Des Moines: State of Iowa); Census of Iowa, 1895 (Des Moines: State of Iowa, 1896); and Census of Iowa, 1925 (Des Moines: State of Iowa, 1926).

3. All persons interviewed who had lived in the coal camps gave the same general account of coal camps as given in the text. Many of the interviewees inquired whether I had heard the popular song by Tennessee Ernie Ford, "I Owe My Soul to the Company Store." They assured me that the song was true. 
same problems eastern producers experienced, particularly the problems of intense competition and overproduction. Iowa officials increasingly felt the effects of competition from larger coal producing states, particularly Illinois. At the same time, Iowa operators and workers had to contend with seasonal layoffs. Because many Iowa operators depended heavily on local consumption of coal for heating purposes, they suffered a heavy decline in sales with the onset of warm weather, and the majority of the state's operators shut down their mines in the late spring and did not reopen until October. Some miners were able to find temporary work as local farm hands, railroad section hands, or construction workers, but most were simply unemployed for the summer months. ${ }^{4}$

The introduction of mining machines further complicated the national mining situation. Beginning in the 1880 s, eastern coal firms began to install undercutting machines which enabled them to produce even more coal. Many larger mines quickly adopted the practice and by 1905 , roughly 25 percent of the nation's total coal production was mined with the use of machines. Mining machines did not become widely used in Iowa, however, until the early 1930s. Even then, because Iowa mines remained small in size and included a wide variety of physical conditions, most operations included both pick and machine mining. ${ }^{5}$

As coal officials struggled with the problems of increased competition, overproduction, and the troublesome "machine question," a change began to take place in the ethnic composition of the miners. Before 1890, English, Welsh, Scottish, and Swedish workers dominated the industry. Operators and miners alike believed that the English-speaking miners particularly were the most skilled because many had learned the trade in their native land. With the influx of large numbers of men

4. Report of the Secretary of the Interior, Part 3 (Washington, D.C.: Government Printing Office, 1896), 55; Arthur Suffern, The Coal Miners' Struggle for Industrial Status (New York: The Macmillan Company, 1926), 12-41. See Adam E. Shurick, The Coal Industry (Boston: Little, Brown, and Co., 1924) for a comprehensive discussion of the problems of overcompetition and overproduction with the coal industry.

5. United Mine Workers Journal, 8 March 1906, 5; and interview with James Battani, Woodward, Iowa, 24 October 1979. 
from southern and central Europe, and the increased use of machines, attitudes toward the miners' work changed. Mining officials began to think that skill or craftsmanship was no longer necessary since a man needed only a "strong back" to operate a mining machine. Increasingly they lamented the passing of the "true craftsmen" - the men who had regarded their work as "almost an occupation."6

\begin{abstract}
As Italians began to immigrate to the United States in ever increasing numbers after 1890 , some chose to locate in Iowa. Unlike the English or Welsh who came seeking a specific job in the mines, the Italians came seeking only work. The coal mines offered that work and, in the process, provided the Italians with a point of entry into American economic life. The typical Italian coming to Iowa was a single male between the ages of sixteen and twenty-four who was emigrating from northern Italy. An example of this typical youth was John Corso who left Italy in 1914 bound for Hocking, Iowa. Corso's uncle had sent him one hundred dollars for the trip, telling him that the coal mines were operating around Hocking and that "anyone could find a job if he were willing to learn the trade." Before coming to the United States, Corso had worked in both France and Austria but neither had proved satisfactory. He commented: "I was a young kid then. I had to do somethin', so finally I wrote to my uncle in Hockin' here, and he send me a hundred dollar, so I bought the ticket." Arriving when he was sixteen years old, Corso worked in the Hocking mines for the next thirty years. ${ }^{7}$

Throughout the immigration and resettlement process, most Italian newcomers relied almost exclusively on assistance from family members or village associates. As one ItalianAmerican phrased it: "Family and village ties monitored the entire migration process; they tied thousands of men and women together, irrespective of where they lived at a particular
\end{abstract}

6. Quoted in Carter Goodrich, The Miner's Freedom: A Study of the Working Life in a Changing Industry (Boston: Marshall Jones Company, 1925), 99-100.

7. Cynthia Johnson, "A New Life: The Iowa Coal Mines," The Palimpsest 56 (March/April 1975): 57. 


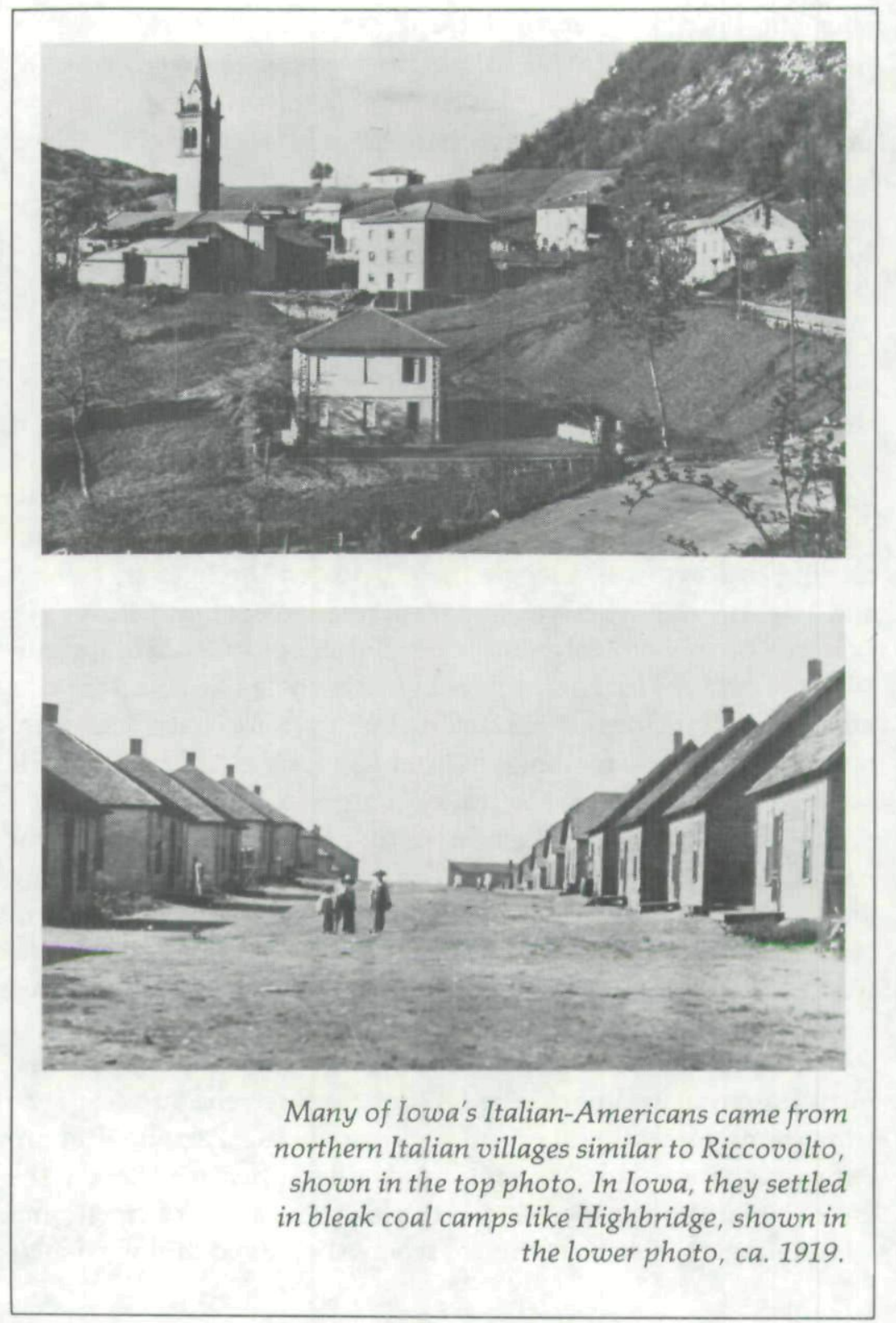


moment; and they provided an entry into local communities." Because most lowa Italians came from poor economic backgrounds, they could seldom leave Italy without sponsors. Typically sponsors were relatives or friends who had already settled in the United States and who provided the immigrants with money for passage and a place to board. Upon his arrival, the newcomer immediately went to work in the mine as an assistant to his sponsor. Both the immigrant and the sponsor benefited from this arrangement. The practice had long existed in American coal mines that a miner received double the number of cars ordinarily assigned on any given day if he took a younger person with him into the mine. Since most miners could load more cars than they were usually assigned, this was an important move. With the assistant, the miner could load out double the amount of coal and, in turn, double his wages. The immigrant also benefited because the practice allowed him to repay the sponsor and at the same time, learn mining procedure. After five or six months, the immigrant could hire on with the coal company as an independent miner. ${ }^{9}$

The second step in the resettling process concerned marriage and the family. Typically the Italian male continued to work until he saved sufficient money to send for his wife or his fiancée. In the event that he wished to marry an Italian woman, but did not have a specific one in mind, he wrote to family members in Italy asking their assistance in helping him find a bride. Sometimes the immigrant sought the help of an older ItalianAmerican in his mining camp, a person known as the "social boss." The position of social boss, a practice carried over from the Old Country, was usually held by a highly respected person who could speak and write both English and Italian. This person assisted newcomers in writing letters, handling legal matters, and applying for naturalization papers. The social boss became a sort of spokesman for the Italian-American families in the community. In cases where a young man desired to marry a young woman from the Old Country but had no contacts there,

8. Virginia Yans McLaughlin, Family and Community: Italian Immigrants in Buffalo, 1880-1930, (Ithaca: Cornell University Press, 1977), 15.

9. Interviews with Ladorrico Sebben and Tony Sebben, Seymour, Iowa, October 1975; John Argenta, Seymour, Iowa, April 1978; and James Battani. 
the social boss would write to friends in Italy and arrange for such a match. ${ }^{10}$

If the miner already had a wife and children in Italy, the process of reuniting the family took longer. The first step was to save money for the wife's passage and possibly that of the youngest child or two. The usual practice was for the older children to stay with relatives in Italy until additional money could be saved for their passage. Once the wife had arrived and money was accumulated for the older children's passage, the family waited until someone from their village was ready to emigrate; arrangements were then made for the children to accompany that adult to the United States.

If the immigrant had not obtained a sponsor, he could count on immediate assistance from fellow Italians once he arrived at his destination. In Seymour which contained a large Italian-American population in the early 1900s, Victor and Angelina Cambruzzi served as the local welcoming committee. The Cambruzzis had made arrangements with all railroad conductors to give incoming Italians instructions on how to reach the Cambruzzi home. When the young men arrived, Angelina Cambruzzi made boarding arrangements for them with local Italian families. Victor Cambruzzi was the Italian social boss in Seymour and assisted the immigrants in getting a job at one of the local coal mines. ${ }^{11}$

Once settled in an Iowa mining community, Italian immigrant families experienced the problems of adjusting Old World traditions and values to their new environment. Although the occupation of coal mining imposed considerable hardships on all family members, the type of work, as well as the geographical location of the mines, provided considerable freedom for the newcomers. In many ways the Italians were moving from small villages in northern Italy to small villages in southern Iowa. The major change came in the form of male employment whereby the male moved out of agricultural work into industrial work. Of considerable importance, however, is

10. Interviews with Flora Betti, Nelli Fontanini, Anita Lami, Lola Nizzi, and Mary Sertich, Granger, Iowa, January 1978.

11. Interviews with Victoria DeGard and Minnie Mores, Seymour, Iowa, October 1975. 
the fact that the setting was rural-industrial as opposed to urban-industrial. Within that work setting the Italian miner, like all coal miners, found himself in a situation quite different from that of other skilled or semi-skilled workers. Once underground, he exercised an almost unprecedented degree of freedom. He worked in an isolated setting with little supervision from company officials. Although the mine foreman was expected to visit each working place daily, in reality he visited the work areas only if the men were encountering difficulty. The coal miner worked at his own pace, established his own procedures, and to a large extent, determined the amount of coal that he loaded out. Throughout the day a miner found it necessary to make a wide range of independent judgements, all of which affected not only his own safety but also the safety of other miners. Company officials and the miners themselves accepted and fostered the concept of miners as independent workmen. As one mining authority pointed out: "There is in fact a strong feeling in the industry, among the bosses as well as among the workers, that the miner is a sort of independent petty contractor and that how much he works and when, are more his own affair than the company's."12 The miner also had the opportunity to take in a helper, thereby doubling the number of cars assigned to him. Many men took their sons into the mines when they reached their fourteenth or fifteenth birthday.

\begin{abstract}
Although the Italian wife was to continue unchanged many of her Old World work habits and traditions, some accommodations were necessary. A major problem facing the Italian families was the coal camp itself. Observers described the camps as unattractive and depressing, noting that there were few trees, shrubs, or even flowers to break the monotonous landscape. Bruna Pieracci, a second-generation Italian-American, recalled the impressions of the first-generation women, including her mother, concerning their new homes in Iowa:
\end{abstract}

The mining camps were quite a contrast to the mountain village in the "old country." They were all alike: clusters of small boxlike houses made of wood and painted gray or boxcar red. These im-

12. Goodrich, The Miner's Freedom, 84. 


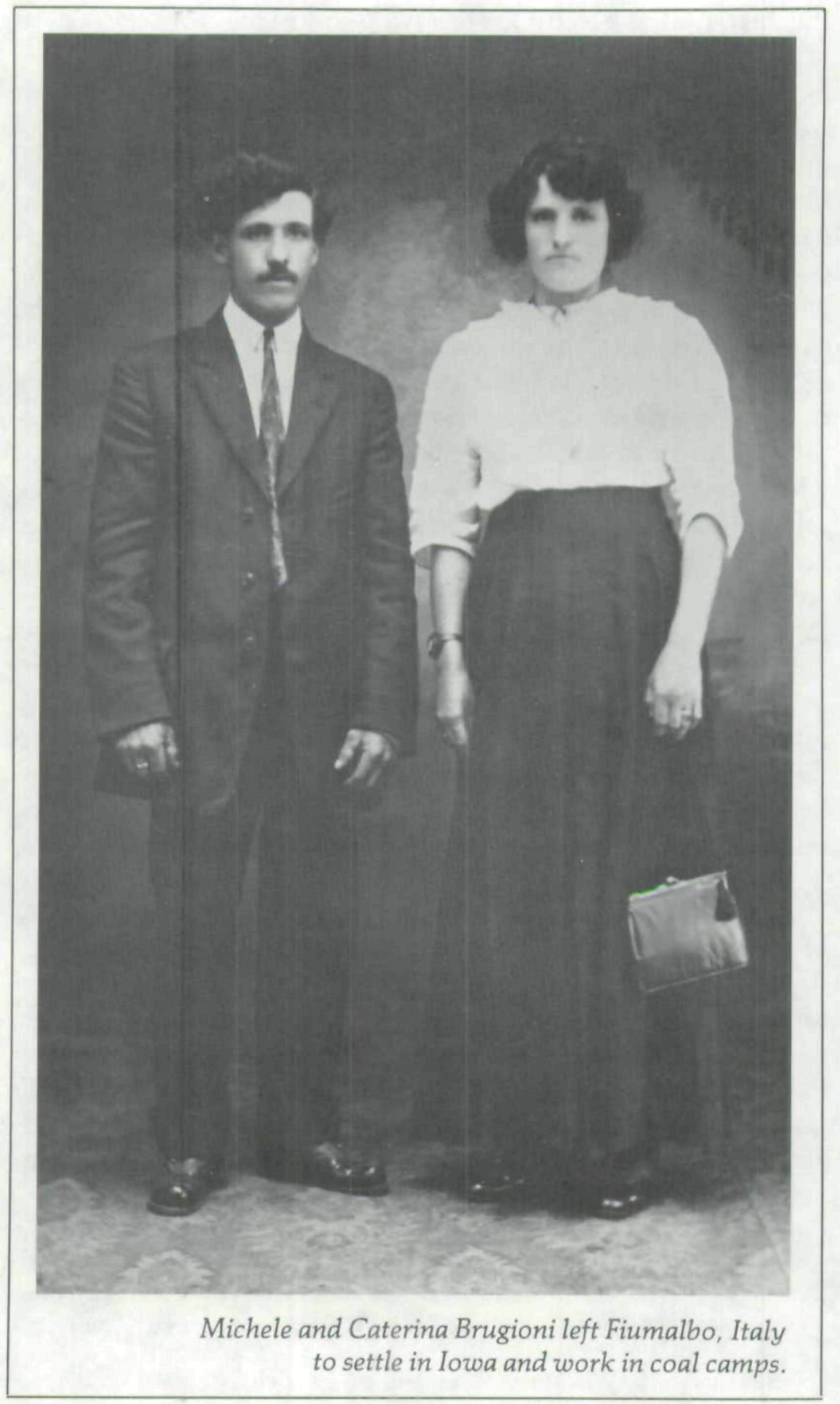


migrants had never seen wooden houses before and they appeared flimsy indeed in comparison to the ancestral homes of stone with walls twenty inches thick. What was even more strange was the absence of trees and shrubbery for this mining camp had been built in the middle of what had been an Iowa cornfield. They were amazed at the flatness of the terrain and among themselves they called it "The Sahara." ${ }^{\prime 13}$

Miners wives also faced other problems with company housing. The typical camp house was small, usually containing four rooms. Moreover, camp residents had difficulty obtaining water. In summer, the local wells often went dry. In winter, they froze up. Because the homes were poorly insulated, they were difficult to heat during the cold Iowa winters. When Angelina Argenta arrived from Italy in 1900 to take up residence in the Big Jim Coal Camp outside of Seymour, she discovered that the company house her husband had rented was "really just a little shack." The house was so poorly constructed that the snow blew in around the windows and covered the bed. ${ }^{14}$

Even with these drawbacks, camp housing contained some advantages. Although the houses were small, each family occupied their own house, thus experiencing some privacy. The coal camps provided no opportunity for women to work outside the home. In the Old Country, Italian males had opposed their wives working outside the home so that tradition was not to be violated. Women were able, however, to earn money by boarding newly arrived Italian coal miners; many women regularly boarded as many as four or five. Several women interviewed followed the practice of renting two houses from the company. The woman's family lived in one while she rented the other to eight or ten miners. The woman then provided the miners with housekeeping services of cleaning, cooking, washing clothes, and packing lunches. The going rate for two weeks of room and board was two dollars per miner. Paulina Biondi recalled that on the day she arrived in Iowa, she immediately took in four

13. Bruna Pieracci, "The Miners," in The Immigrants Speak: ItalianAmericans Tell Their Story, ed. Salvatore J. LaGumina (New York: Center for Migration Studies, 1979), 35.

14. Interview with Elnora Earls, Seymour, Iowa, March 1978. 
boarders. The family lived in two rooms and managed by hanging a burlap curtain between the kitchen where she and her husband slept and the bedroom where the four miners slept. For the next forty years this woman raised a family of five children as well as keeping a minimum of four boarders at all times. During much of that time the family lived in a four-room company house. She recalled that the worst time was when two of the boarders worked the night shift and had to sleep during the day while the other two men worked the day shift and slept at night. The beds were in constant use. During all the years that Biondi kept boarders she arose at four o'clock in the morning to bake either a pie or cake so "the men would have something sweet to take in their lunch buckets."15

Biondi's experience reflects the domestic activity carried on by most Italian-American women who lived in coal mining communities. The activities varied at times, with women earning money by sewing for neighbors, selling garden produce, or working as midwives. In other cases, savings were realized because the women raised chickens, pigs, and kept cows, along with producing large quantities of fruits and vegetables. One first-generation woman, Antonia Cerato, recalled that in addition to keeping two or three boarders, she milked twelve cows every day. This enabled her to provide dairy products for her family as well as realizing a considerable profit from the sale of excess milk and cream. Significantly, while the women were carrying out these functions, they were able to remain in their homes, caring for their children and otherwise performing their domestic duties. The Italian woman could carry over the time honored roles of wife and mother into the Iowa experience. Moreover, the resettlement did not disrupt the equally time honored practice of the Italian male as breadwinner. Regardless of the meager amount earned by the male, he clearly remained the head of the household. In this sense, the Iowa experience did not cause a breakdown in Italian family structure or in the family's patriarchal organization. ${ }^{16}$

\section{Interview with Paulina Biondi.}

16. Interview with Antonia Cerato, Numa, Iowa, March 1978; and interviews with Flora Betti, Nelli Fontanini, Anita Lami, Lola Nizzi, and Mary
Sertich. 


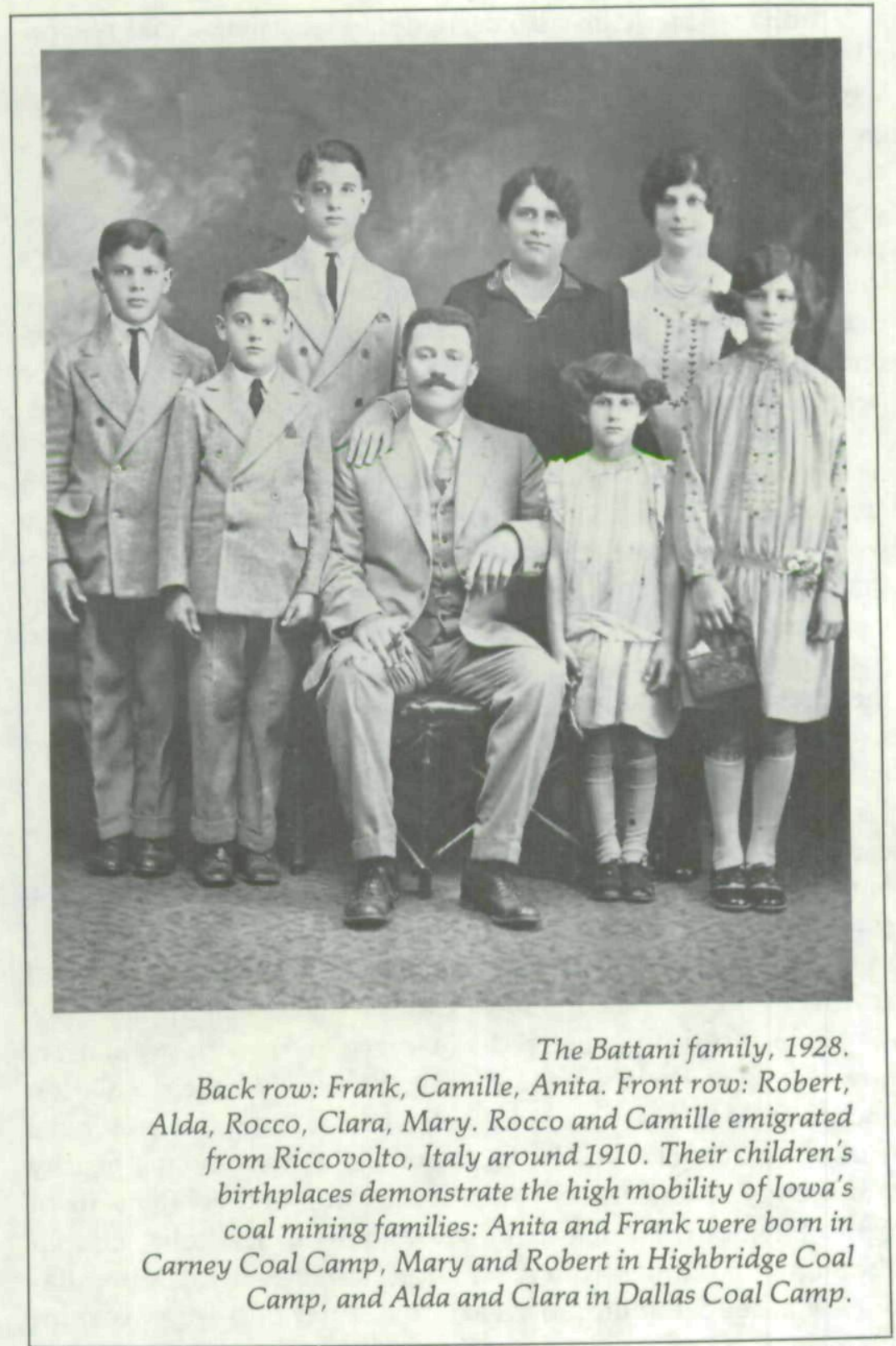


Italian-Americans also carried their sense of social responsibility from the Old World to the new. Many Italian-American women remembered the sharing and the fellowship that existed in the mining camps. If anyone became ill, other families responded by bringing in food, helping with the children, and assisting with housework. According to Father John Gorman, parish priest at Granger, Iowa for over thirty years, there was a great sense of social responsibility among the Italian-Americans in the mining camps. Father Gorman commented that "If someone died, some other family took over the children. Everyone helped everyone else." The foster family usually would not adopt the child but would provide the child with a home until he or she reached working age. Lola Nizzi added, "It was a comforting thought to the people that you knew your family would be taken care of if anything happened to you. You knew that the family would be cared for. They helped each other."17

Mining families also offered assistance to neighbors and friends that helped ease the frequent tragedies in their lives. In the Dallas Coal Camp, Mike and Caterina Brugioni often assisted their neighbors in times of distress. When a death occurred in the mine and local officials were reluctant to tell the family, Caterina Brugioni bundled up and headed out over the fields to carry the news herself. Sometimes she helped the family by bathing and preparing the corpse for burial. Mike Brugioni sometimes helped make coffins for infants and babies who died in the community. He and Father Gorman made a number of coffins in the shop of the local Catholic high school. ${ }^{18}$

One institution that did not carry over with regularity, however, was the Catholic church. Because of their isolation and their temporary nature, most coal camps did not have Catholic places of worship. Occasionally a priest from a nearby community would travel to the local camp and conduct mass. From Seymour, which has never had a Catholic church although it continues to have a large Italian-American population, Catholic families traveled to Centerville for worship. Victoria DeGard, a second-generation Italian-American, re-

17. Interviews with Father John Gorman, Elkhart, Iowa, July 1977 and January 1978; and interview with Lola Nizzi.

18. Interview with Nelli Fontanini. 
membered that her mother never forgave her father for taking her to a place that did not have a Catholic church. The mother insisted that at least once a year the family go to Centerville, where the nearest church was located. She always decided that as long as they were there, they would stay for several masses. Apparently for many Italians, leaving the church behind was not all that bad. In the late nineteenth century, northern Italians in particular were strongly anti-clerical and many came to Iowa with hostile feelings toward the Catholic church. For many of these people, especially the men, there was little anguish that the church was out of their lives. ${ }^{19}$

IN examining the immigration patterns of the ItalianAmericans in Iowa it appears that coal mining not only provided the Italians with a point of entry into American economic life, but also allowed the process to take place with a minimum of alienation and upheaval. Within that experience, the transition from the Old Country to the Iowa countryside was softened and eased all along the way by family and friends. The rural industrial setting seemed to allow a carry-over of at least some Old World practices. The occupation of mining allowed the Italian male to be largely an independent workman. Although work in an lowa coal mine was far removed from work in an Italian vineyard, it seems that digging coal imposed fewer difficulties and required fewer adjustments for Italians locating in Iowa than for those faced by Italians immigrating to the cities. The Iowa coal mines allowed the Italians to escape factory work which they universally wished to avoid. The slow mechanization of Iowa mines also allowed Italian miners largely to escape working with machines. If, as some scholars maintain, Italian immigrants were attempting to avoid the time restraints and close supervision imposed by factory work, then the coal mines offered an acceptable alternative. Moreover, with all its bleakness, the coal camp allowed the Italian women

19. Interview with Victoria DeGard; and Rudolph Vecoli, "Peasants and Prelates: Italian Immigrants and the Catholic Church," Journal of Social History 2 (Spring 1969): 222-223. 
to carry on their traditional roles as wives and mothers, leaving the Old World family structure carefully intact. ${ }^{20}$

The Italians made good coal miners. Contrary to the view that persisted early in this century that only miners trained in the Old Country could be real craftsmen, the Italians seemed equally qualified. In Iowa, Italian miners worked at all jobs within the mine, learning how to handle a pick as well as learning how to work a machine. Some also rose into the ranks of management. Of the Italian-Americans interviewed, four men eventually became mine foremen while five more became mine owners.

Finally, nowhere in history of the Italian-Americans in Iowa does one find the type of shattering, alienating experience described by Oscar Handlin and other immigration historians. In considering their total cultural experience, the ItalianAmericans who settled in Iowa's coal mining communities seemed to have adjusted with a minimum of difficulty. The first generation came with the firm conviction that life would be better in America. They were not disappointed; life was better in America even though everyone had to work very hard. But as one Italian-American woman observed: "Everyone had to work very hard here but then no one ever told us that life would be easy in America." 21

20. Interviews with Flora Betti, Nelli Fontanini, Anita Lami, Lola Nizzi, and Mary Sertich.

21. Oscar Handlin, The Uprooted (Boston: Little, Brown, and Co., 1951); and interview with Nelli Fontanini. 
Copyright of Annals of Iowa is the property of State of Iowa, by \& through the State Historical Society of Iowa and its content may not be copied or emailed to multiple sites or posted to a listserv without the copyright holder's express written permission. However, users may print, download, or email articles for individual use. 